Article

\title{
Soot Particle Size Distribution, Regulated and Unregulated Emissions of a Diesel Engine Fueled with Palm Oil Biodiesel Blends
}

\author{
Jun Cong Ge and Nag Jung Choi * \\ Division of Mechanical Design Engineering, Jeonbuk National University, Jeonju-si 54896, Korea; jcge@jbnu.ac.kr \\ * Correspondence: njchoi@jbnu.ac.kr; Tel.: +82-63-270-4765
}

Received: 6 October 2020; Accepted: 27 October 2020; Published: 2 November 2020

check for updates

\begin{abstract}
In this study, five fuels including pure diesel (B0), pure palm oil biodiesel (B100), and their blends (B10, B20, and B30) were investigated in relation to soot particle distribution and regulated and unregulated emission characteristics in a common rail direct injection (CRDI) diesel engine. The results indicated that $\mathrm{CO}$, hydrocarbon $(\mathrm{HC})$, and particulate matter $(\mathrm{PM})$ regulated emissions were effectively controlled to a very low level by combining the addition of palm oil biodiesel (POB) to diesel with optimized engine operating conditions. Paper filters and TEM grids were used to capture the diesel particles. All the PM primary particles were less than $100 \mathrm{~nm}$ in diameter observed by TEM, and the average diameters of the PM primary particles for the biodiesel blends were distributed between 20 and $26 \mathrm{~nm}$. Unregulated emissions such as trace metals including $\mathrm{Pb}, \mathrm{Mn}$, and $\mathrm{Ba}$ were found in the PM particles, and the xylene, toluene, and benzene unregulated emissions of B100 were reduced by $55.68 \%, 21.56 \%$, and $18.32 \%$, respectively, compared to those of B0. Therefore, POB is an excellent alternative fuel for diesel engines and has great application potential to solve the current pollution problems of regulated and unregulated emissions.
\end{abstract}

Keywords: palm oil biodiesel; engine load; regulated emissions; unregulated emissions

\section{Introduction}

Diesel engines have been used widely in applications such as commercial vehicles, passenger cars, power generators, and construction equipment due to their high thermal efficiency, reliability, and large output power [1,2]. However, high nitrogen oxide (NOx) and particulate matter (PM) emissions are significant drawbacks of diesel engines [3,4]. The large presence of NOx and PM emissions poses a huge threat to the ecological environment and human health. Many researchers have reported that the formation of haze is related to diesel engine emissions, and long-term exposure to haze pollution will directly increase the morbidity and mortality of respiratory and cardiovascular diseases [5]. It is well known that the relationship between PM and NOx emissions is a tradeoff, which makes it difficult to reduce PM and NOx simultaneously using traditional engine technology. Although some new combustion technology, such as low temperature combustion (LTC) [6] and diesel exhaust aftertreatment devices (e.g., DOC: Diesel Oxidation Catalyst; DPF: Diesel Particulate Filter; and SCR: Selective Catalytic Reduction) [7], can limit the regulated emissions (i.e., CO, hydrocarbon (HC), NOx, and PM) to a low value, they will increase purchase and maintenance costs, which is uneconomical. In addition, these technologies do not have more information for the reduction of unregulated emissions from diesel engines, such as trace metals (TMs) and volatile organic compounds (VOCs).

Generally, the ways to reduce engine emissions mainly include improving the fuel injection system (e.g., fuel injection timing and pressure and single or multiple injection), optimizing the air-fuel ratio (e.g., variable valve timing system and turbocharger), using exhaust aftertreatment systems (e.g., DOC, 
DPF, and SCR), and improving fuel properties (e.g., biodiesel and oxygenated fuel). Considering the cost and technical limitations of other alternatives, optimizing fuel properties has great application potential to improve engine performance and emissions by using, for example, biodiesel, oxygenated fuels, and fuel additives. The development and utilization of biodiesel has always been one of the most important research topics for researchers all over the world due to its rich resource, green, renewable, environmentally friendly, and other advantages.

Biodiesel, also known as a mixture of fatty acid methyl or ethyl esters, can be extracted from a variety of renewable feedstocks, such as animal fats [8], vegetable oil [9], algal biomass [10], and waste cooking oil [11], via transesterification; it can be used in diesel engines directly or by blending it with diesel without any modification due to the fact that its fuel properties are similar to diesel [12]. Moreover, biodiesel can effectively improve engine combustion efficiency and reduce $\mathrm{CO}, \mathrm{HC}$, and PM emissions due to its high oxygen content and high cetane number [13]. However, using pure biodiesel for diesel engines will lead to poor atomization, injector coking, cold start problems, high fuel consumption, and other problems due to its high viscosity and low calorific value. Therefore, blending biodiesel and diesel is a simple and effective way to solve the above problems. Many researchers have reported that a variety of biodiesel-diesel blended fuels can effectively reduce $\mathrm{CO}, \mathrm{HC}$, and PM emissions, such as waste cooking oil biodiesel [14], jatropha oil biodiesel [15], karanja oil biodiesel [16], canola oil biodiesel [17], soybean oil biodiesel [18], and palm oil biodiesel [19]. However, numerous studies on biodiesel have only focused on the torque, combustion pressure, fuel consumption, and endurance in specific diesel engines (e.g., in single cylinder engines or engines with some modifications) [20] under partial operating conditions (e.g., constant engine speed or load) $[17,21]$. There have been few studies on PM morphology and unregulated emissions such as trace metals and VOCs from diesel engines fueled with biodiesel blends. Salamanca et al. [22] used a Teflon filter to capture particulate matter emitted from a diesel engine fueled with palm oil biodiesel, then dispersed the PM in ethanol via an ultrasonic bath, and finally analyzed the size and morphology of the particles by TEM. The disadvantage of this method is that the steps are too complicated and unequal to ensure that the morphology of the particles does not change in the ultrasonic treatment process. Some semi-automatic measurement methods have also been used to analyze the size of the primary particles $[23,24]$. On the other hand, although Ferreira et al. [25] and Shukla et al. [26] studied the volatile organic compounds (VOCs) and trace metals emitted from diesel engines, they did not report the relationship between the emission and combustion characteristics.

Therefore, to further investigate the combustion and emission characteristics of palm oil biodiesel, especially the morphology and microstructure of particles and unregulated emissions, including VOCs and trace metals, this experimental investigation was carried out on a four-cylinder common rail direct injection (CRDI) diesel engine without any modification at various engine loads from $0 \%$ to $100 \%$. Five palm oil biodiesel blends were selected as the main test targets. In this study, two simple and practical PM primary particle capture methods were used, which provide an effective reference for the analysis of PM morphology, including nanostructure and size. These methods have potential application value for further analysis of the physicochemical characteristics of PM particles emitted from diesel engines in the future.

\section{Experimental Setup and Procedure}

\subsection{Test Fuels}

Five blended fuels were prepared through blending pure palm oil biodiesel at $0 \%, 10 \%, 20 \%, 30 \%$, and $100 \%$ by volume with neat diesel, which corresponded to B0, B10, B20, B30, and B100, respectively. The specific properties of the tested fuels are listed in Table 1. As shown in Table 1, it can be clearly seen that the palm oil biodiesel has a higher density, viscosity, cetane index, and lower calorific value than diesel. Moreover, this biodiesel also contains about $11.26 \%$ oxygen. These important physical properties are related to the combustion and emission characteristics described in Section 3. 
Table 1. Properties of B0, B10, B20, B30, and B100.

\begin{tabular}{cccccc}
\hline Properties (Units) & B0 & B10 & B20 & B30 & B100 \\
\hline Density $\left(\mathrm{kg} / \mathrm{m}^{3}\right.$ at $\left.15^{\circ} \mathrm{C}\right)$ & 836.8 & 841 & 845 & 849 & 877 \\
Viscosity $\left(\mathrm{mm}^{2} / \mathrm{s}\right.$ at $\left.40{ }^{\circ} \mathrm{C}\right)$ & 2.719 & 2.893 & 2.991 & 3.173 & 4.56 \\
Calorific value $(\mathrm{MJ} / \mathrm{kg})$ & 43.96 & 43.43 & 42.83 & 42.31 & 39.72 \\
Cetane index & 55.8 & - & - & - & 57.3 \\
Flash point $\left({ }^{\circ} \mathrm{C}\right)$ & 55 & - & - & - & 196.0 \\
Oxidation stability $\left(\mathrm{h} / 110^{\circ} \mathrm{C}\right)$ & 25 & - & - & - & 9.24 \\
Oxygen content $(\%)$ & 0 & - & - & - & 11.26 \\
\hline
\end{tabular}

\subsection{Test Engine and Operating Methods}

This experimental research was investigated in a four-cylinder turbocharged CRDI diesel engine (2004 Hyundai Santa Fe, Ulsan, Korea) with a displacement of 1991cc. The tested engine was not equipped with an exhaust aftertreatment system. The detailed engine specifications are summarized in Table 2. Figure 1 shows a schematic of the experimental setup. An eddy-current-type eddy current (EC) dynamometer was employed to control engine speed and engine load. Moreover, a high-precision digital electronic weighing balance (GP-100K, A\&D Co. Ltd., Tokyo, Japan) was used to measure fuel consumption; the in-cylinder pressure was measured by a piezoelectric pressure sensor (Type 6056A, Kistler Korea Co., Ltd., Gyeonggi-do, Korea). The in-cylinder pressure value with crank angle was recorded from 200 engine cycles to calculate the heat release rate (HRR) for analyzing combustion characteristics. All combustion data were acquired using a National Instruments PCI-6040E (National Instruments, Austin, TX, USA) data acquisition (DAQ) board. The CO, HC, and NOx emissions were measured by a MK2 (GreenLine MK2, Eurotron (Korea) Ltd., Seoul, Korea) and HPC-501 (Nantong Huapeng Electronics Co., Ltd., Jiangsu, China) multi-gas analyzer. The smoke opacity of the exhaust gas was measured with an OPA-102 (QROTECH Co., Ltd., Gyeonggi-do, Korea) smoke meter. Five engine loads of $0,35,70,105$, and $140 \mathrm{Nm}$, corresponding to $0 \%, 25 \%, 50 \%, 75 \%$, and $100 \%$, were selected as the main experimental variable to test the biodiesel blends. The engine speed and the pilot and main injection timings were fixed at $1500 \mathrm{rpm}, 24^{\circ}$ before top dead center (BTDC), and $4^{\circ}$ BTDC, respectively. Detailed operating conditions are listed in Table 3. Figure 2 shows the detailed flow charts of this experiment.

Table 2. Specifications of the test engine.

\begin{tabular}{ccc}
\hline Engine Parameter & Units & Specifications \\
\hline Type & - & turbocharged CRDI diesel engine \\
Number of cylinders & - & 4 \\
Bore $\times$ stroke & $\mathrm{mm}$ & $83 \times 92$ \\
Injector hole diameter & $\mathrm{mm}$ & 0.17 \\
Compression ratio & - & $17.7: 1$ \\
Max. power & $\mathrm{kW} / \mathrm{rpm}$ & $82 / 4000$ \\
\hline
\end{tabular}

Table 3. Experimental and operating conditions.

\begin{tabular}{cc}
\hline Item & Conditions \\
\hline Test fuels & $\mathrm{B} 0, \mathrm{~B} 10, \mathrm{~B} 20, \mathrm{~B} 30, \mathrm{~B} 100$ \\
Engine loads & $0 \%, 25 \%, 50 \%, 75 \%, 100 \%$ \\
Engine speed & $1500 \mathrm{rpm}$ \\
Fuel injection pressure & $60 \mathrm{MPa}$ \\
Pilot injection timing & $24^{\circ} \mathrm{BTDC}$ \\
Main injection timing & $4^{\circ} \mathrm{BTDC}$ \\
Intake air temperature & $25 \pm 3^{\circ} \mathrm{C}$ \\
Cooling water temperature & $85 \pm 3^{\circ} \mathrm{C}$ \\
\hline
\end{tabular}




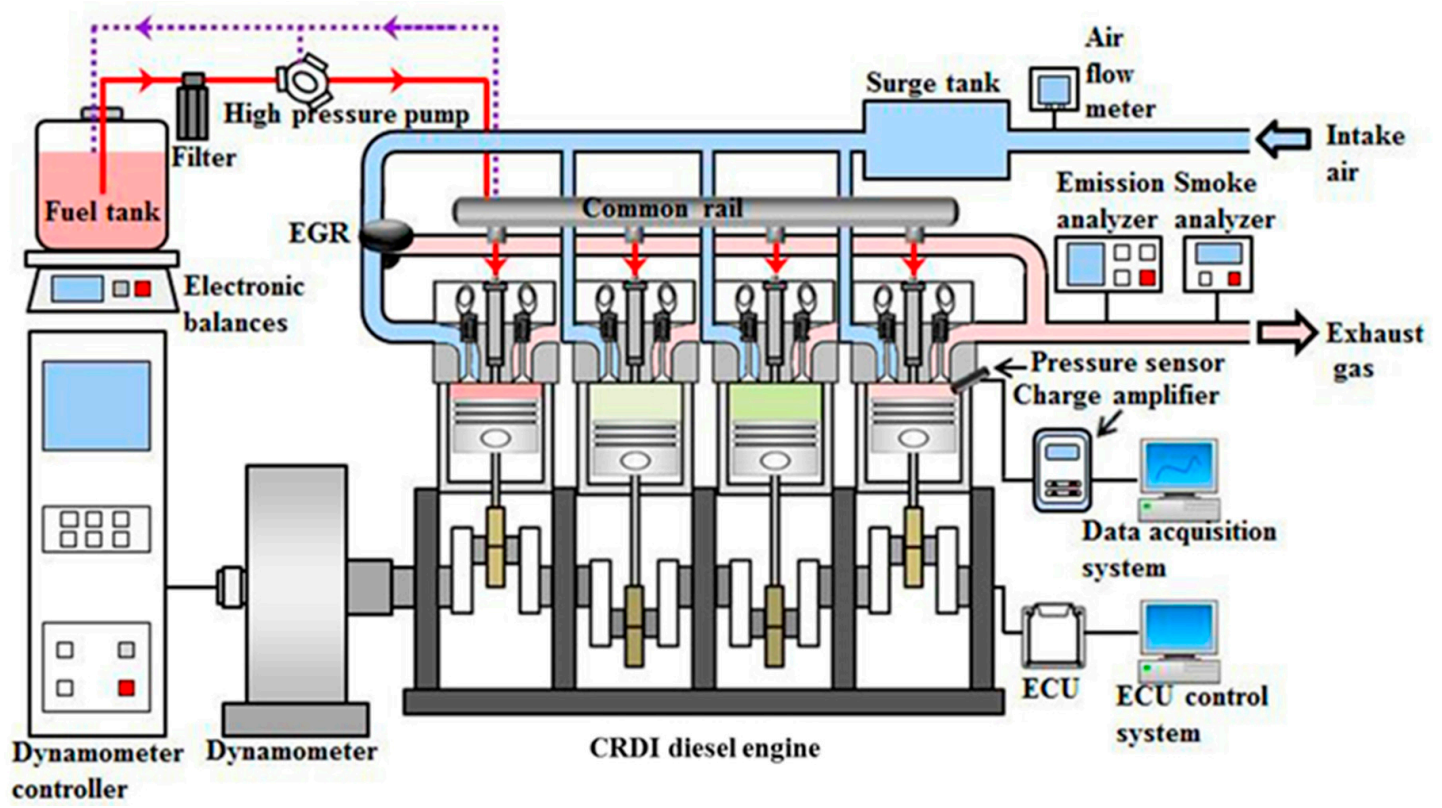

Figure 1. Schematic diagram of the experimental apparatus.

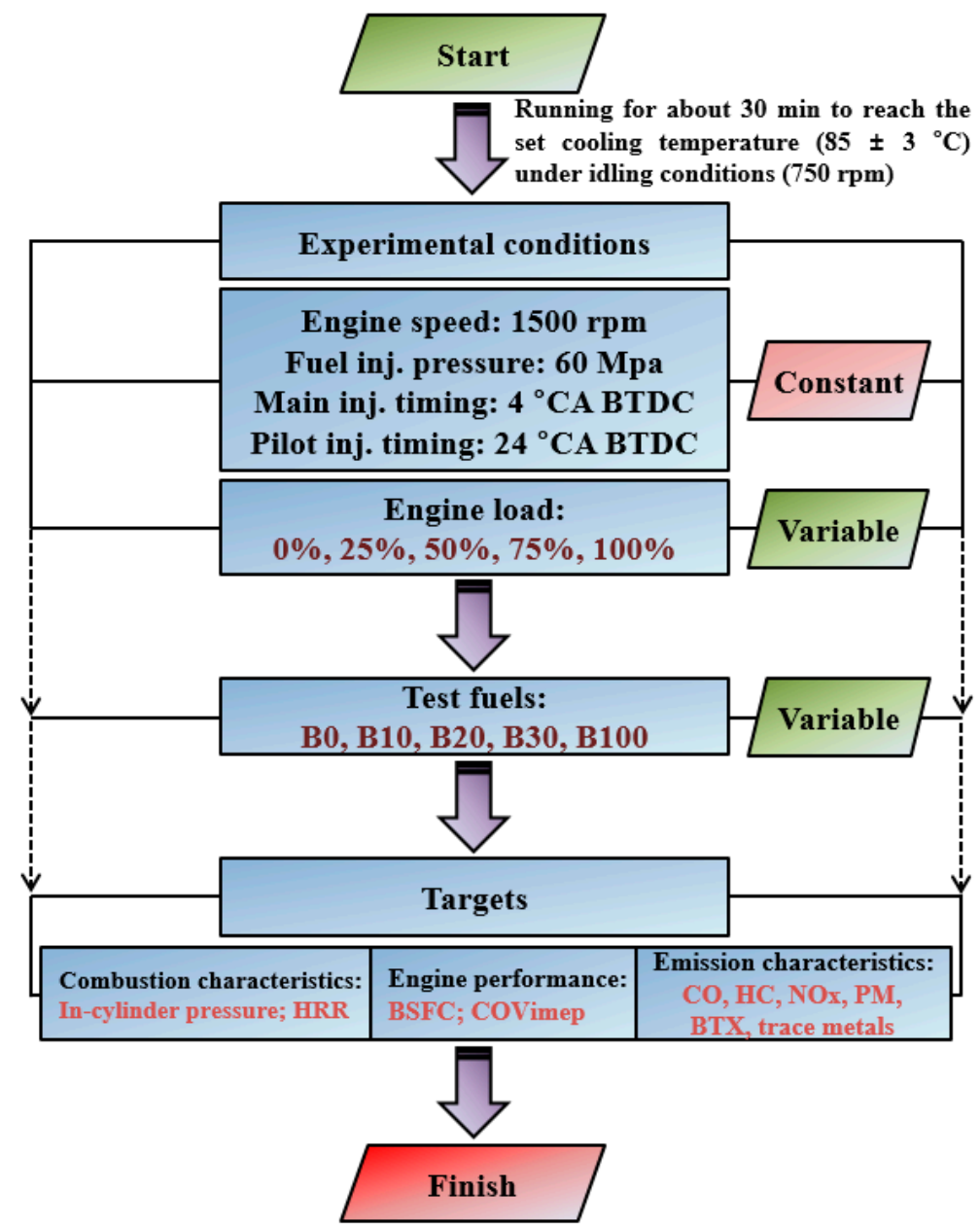

Figure 2. Flow chart for the engine experiment. 


\subsection{PM Sampling System and Analysis Method}

To observe the structure and morphology of PM primary particles, a 400 mesh transmission electron microscope (TEM) grid (Type: FCF400-Cu) was used to collect the PM primary particles from all tested fuels at $25 \%$ and $75 \%$ loads. Then, the TEM (H-7650 with $0.2 \mathrm{~nm}$ resolution; Hitachi High Technologies, Tokyo, Japan) and field emission scanning electron microscopy (FE-SEM; SUPRA 40 VP; Carl Zeiss, Germany) were used to observe and analyze the micromorphology, nanostructure, and size of the PM primary particles loaded on the TEM grid. The magnifications of the TEM and SEM were 200.00 and $250.00 \mathrm{KX}$, respectively. The diameter of the PM primary particles loaded on the TEM grid was measured by ImageJ software. In addition, to further observe the effect of the biodiesel blends on the PM emissions, the PM primary particles were also collected for one and two minutes on a soot determination filter paper ( $\varnothing 45 \mathrm{~mm})$ under full load. These samples were then analyzed by the above SEM with a magnification of $1.00 \mathrm{KX}$.

\subsection{Benzene, Toluene, and Xylene (BTX) Emissions Sampling System and Analysis Method}

The exhaust gas emitted from the CRDI engine fueled with the five tested fuels at loads of $25 \%$ and $75 \%$ was collected in 5 L Tedlar (TDAP05, Aluminum Gas Sampling Bag, LKLABKOREA Inc., Gyeonggi-do, South Korea) gas sampling bags. While collecting the gas, a stainless-steel pipe with a diameter of $50 \mathrm{~mm}$ was used to cool the exhaust gas and maintain it at roughly $45^{\circ} \mathrm{C}$. Then, a high-precision air flow pump was employed to mix the collected gas with high-purity nitrogen $(99.99 \%)$ at a ratio of 1:19. In order to avoid a photochemical reaction between the BTX and NOx emissions in the presence of sunlight, all BTX operations were carried out in the absence of sunlight. The diluted BTX emissions were analyzed using a purge and trap analyzer (JDT-505II/2010GC/QP2010MS, Japan Analytical Industry, Tokyo, Japan). The JDT-505II and 2010GC/QP2010MS were used for purge and trap sampling and qualitative and quantitative analysis of BTX emissions, respectively. Detailed testing methods have been documented in our previous studies [27].

\subsection{Trace Metals Sampling System and Analysis Method}

In general, the trace metals (TMs) are loaded on PM primary particles and then discharged into the atmosphere with PM primary particles. Thus, in order to capture TMs, the PM primary particles of all tested fuels were collected for five minutes on a soot determination filter paper ( $\varnothing 45 \mathrm{~mm}$ ) under full engine load. Then, an inductively coupled plasma mass spectrometer (ICP-MS; iCAP RQ; Thermo Fisher Scientific) was used to measure the TMs. The detailed experimental steps were as follows: the samples were first cut with scissors and placed in a Teflon vessel containing aqua regia (nitric acid: hydrochloric acid $=1: 3$ ), reacted for $24 \mathrm{~h}$ at room temperature, and then the reaction solution with the samples was heated to $180^{\circ} \mathrm{C}$ and microwaved for $20 \mathrm{~min}$. After the temperature returned to room temperature, the reaction solution with the samples was poured into a $50 \mathrm{~mL}$ tube and finally diluted to a $50 \mathrm{~mL}$ precursor solution by adding $2 \%$ nitric acid solution for ICP-MS analysis.

\section{Results and Discussion}

\subsection{Combustion Characteristics}

The combustion characteristics of the biodiesel blends can be quantified using in-cylinder pressure (IP) and heat release rate (HRR). Figure 3 shows the influences of various biodiesel blends on IP at engine loads from $0 \%$ to $100 \%$. As shown in Figure 3, the combustion processes of all tested fuels were the same, including a phase of premixed combustion and a phase of diffusion combustion, which was the dual burning mode of diesel engine combustion [28]. On other hand, the peak IP of all tested fuels appeared after top dead center (ATDC) $8^{\circ} \sim 15^{\circ}$ crank angle (CA) under all operating conditions. This indicates that the CRDI diesel engine fueled with biodiesel blends could run well under various loads, because peak IP occurring very close to TDC or before has a negative effect on engine knock and durability [29]. Overall, all the biodiesel blends had similar pressure profiles to diesel at each load. The 
mixing ratio of biodiesel had little effect on IP at $0 \%$ and $25 \%$ loads. However, the temperature and pressure in the combustion chamber began to rise sharply and form a high temperature and pressure combustion environment under medium and high loads. Based on this environment, the physical and chemical properties of biodiesel activate, the negative effects of biodiesel, such as high density and high viscosity, weaken, and the oxygen in biodiesel promotes combustion, so that the IP of B30 is greater than that of B0; the IP of B30 increased most at the $75 \%$ load, about $2.05 \%$ compared with B0. On the other hand, another disadvantage of biodiesel is its low calorific value compared to diesel, which results in the IP of B100 being lower than that of B0 [30]. In addition, the peak IP rose significantly with increasing engine load for all tested fuels, which may be due to the increase in fuel quantity requirement and entrained-air volume. In Figure $3 a, b$, the in-cylinder pressure curve for B100 at $0 \%$ and $25 \%$ low engine loads rose relatively earlier than other tested fuels at high loads. These results were in agreement with Dhar et al. [31].

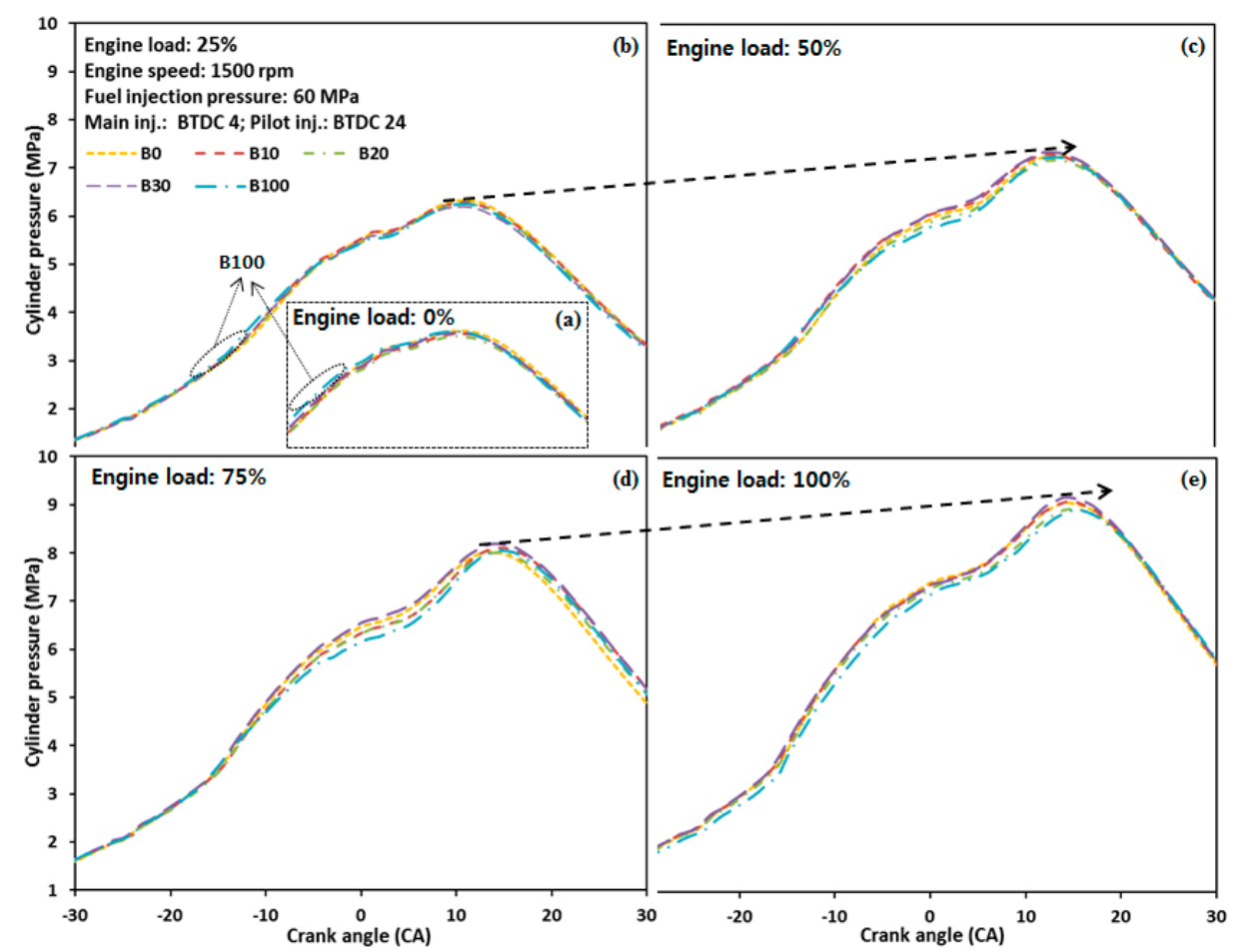

Figure 3. Effect of biodiesel blends on in-cylinder pressure at each engine load. (a) Engine load: 0\%; (b) Engine load: 25\%; (c) Engine load: 50\%; (d) Engine load: 75\%; (e) Engine load: 100\%.

Figure 4 describes the variation of the HRR according to various biodiesel blends at each engine load. It can be seen that no significant correlation can be drawn between the biodiesel blends and the peak HRR. The undulating peak HRR values of biodiesel blends can be attributed to the following reasons: (i) high viscosity and high density are not conducive to fuel atomization; (ii) low calorific value reduces the peak values of in-cylinder pressure and HRR; (iii) oxygen in biodiesel and a high cetane index improve combustion characteristics, which is helpful for increased in-cylinder pressure and HRR. The first and second reasons are negative factors on increasing in-cylinder pressure and HRR, and the third reason is a positive factor. Therefore, all the properties of biodiesel, including both advantages and disadvantages, should be taken into account when evaluating the combustion characteristics of biodiesel blends. 

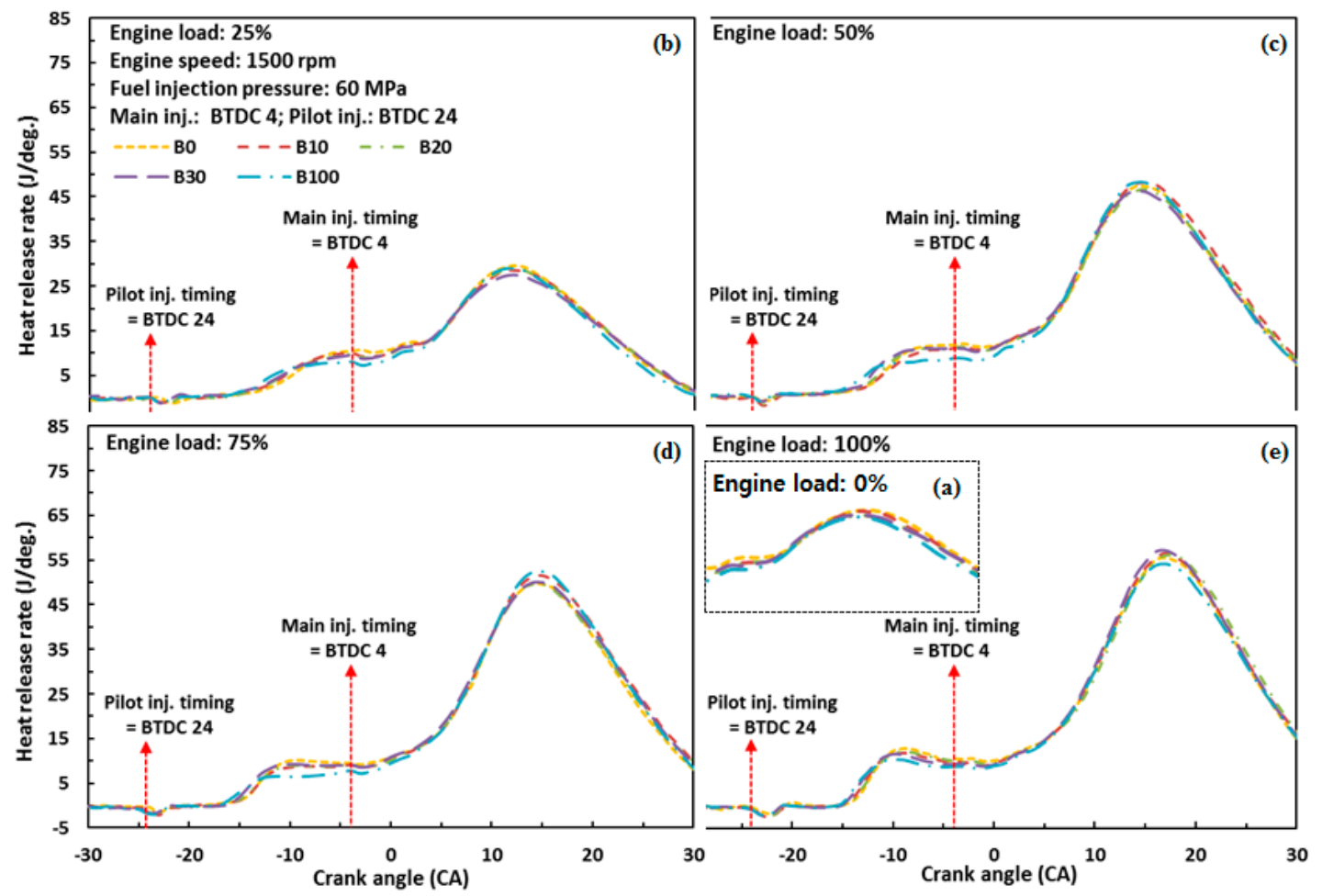

Figure 4. Effect of biodiesel blends on heat release rate at each load. (a) Engine load: $0 \%$; (b) Engine load: 25\%; (c) Engine load: 50\%; (d) Engine load: 75\%; (e) Engine load: 100\%.

\subsection{Engine Performance}

Figure 5 shows the brake specific fuel consumption (BSFC) and the coefficient of variation of the indicated mean effective pressure (COVimep) for all tested fuels according to various loads. As shown in Figure 5a, with the increase in engine load from 25\% to $100 \%$, the BSFC of all tested fuels initially decreases and then increases slightly at full load. The main reason for the decrease is that the increasing percentage of fuel required for engine operation is less than the increasing percentage of brake power due to relatively low heat loss at medium and high loads [32]. On the other hand, the BSFC increases significantly with an increasing biodiesel ratio in diesel. This is a main contribution to biodiesel having a lower calorific value than diesel, leading to biodiesel and biodiesel-diesel blends consuming more fuel to produce the same power as diesel. Other researchers have also found these results [33]. In Figure $5 b$, it can be seen that the COVimep is significantly reduced for all tested fuels as the load increases from $0 \%$ to $50 \%$ but then it increases slightly at the $75 \%$ and $100 \%$ loads. It is worth noting that the COVimep of all tested fuels is much lower than $10 \%$ under all operating conditions. It can be shown that the engine can run very stably under these parameters, because the upper limit of COVimep is $10 \%$ [34]. 

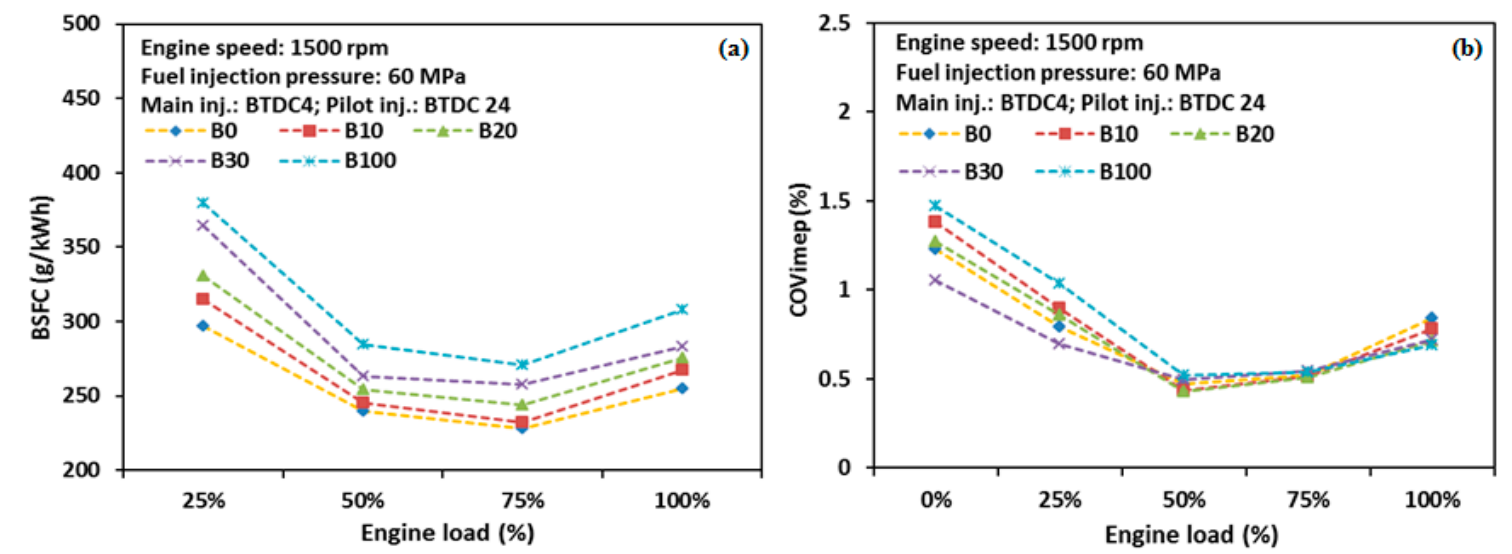

Figure 5. Variation of (a) brake specific fuel consumption (BSFC) and (b) the coefficient of variation of the indicated mean effective pressure (COVimep) for various biodiesel blends.

\subsection{Regulated Emission Characteristics}

Figure 6 shows the effect of biodiesel blends on regulated emission characteristics. As shown in Figure $6 \mathrm{a}$, the $\mathrm{CO}$ emissions are higher at $\% \%$ load than at other operating conditions, and $\mathrm{CO}$ emissions decrease significantly as the load increases. The higher the engine load, the higher the combustion temperature and pressure, and the more complete combustion is, which contributes to the overall decrease in $\mathrm{CO}$ emissions. The slight increase in $\mathrm{CO}$ at full load may be due to the large amount of fuel consumed to obtain greater output power, at which time the concentration of oxygen in the combustion chamber is reduced, thereby slowing down the oxidation rate of CO [35]. Uyumaz et al. [34] noted that $\mathrm{CO}$ is a harmful exhaust gas that is mainly emitted as the result of incomplete combustion, and $\mathrm{CO}$ emissions increase when the temperature and oxygen in the combustion chamber are insufficient. In addition, $\mathrm{CO}$ emissions decrease substantially as the biodiesel ratio in diesel increases. The reduction of $\mathrm{CO}$ in $\mathrm{B} 100$ at $50 \%$ load is greater than that under other operating conditions and is about $82 \%$ lower than that of $\mathrm{B} 0$ under the same conditions. This is mainly because the oxygen contained in the biodiesel plays a decisive role, increasing the oxygen concentration during the combustion process and making the fuel burn more thoroughly. Figure $6 \mathrm{~b}$ compares the unburned hydrocarbon (HC) emissions for all tested fuels. Based on the overall analysis, increasing the load from $0 \%$ to $100 \%$ has a much smaller effect on $\mathrm{HC}$ emissions than on $\mathrm{CO}$ emissions. The range in $\mathrm{HC}$ concentrations at various loads is $65 \mathrm{ppm}$. The HC emissions for all biodiesel blends are less than those for diesel. This reduction in $\mathrm{HC}$ emissions may be due to changes in the stoichiometry of the spray caused by the oxygen in biodiesel [36]. In addition, the biodiesel has a higher cetane index (57.3) than the diesel (55.8), resulting in more complete combustion in the cylinder, which also contributes to the low HC emissions [37]. As shown in Figure 6c, for all tested fuels, the NOx emissions increase significantly with the gradual increase in the load. The NOx emissions of B0 and B100 at 100\% engine load are increased by $849.28 \%$ and $848.45 \%$, respectively, relative to those at $0 \%$ load. In addition, the biodiesel blend ratio in diesel fuel has a greater impact on NOx emissions at a high load than at a low load. The diffusion flame combustion process dominates at a high load, and the effect of engine control on NOx emissions emitted from biodiesel is more significant. On the other hand, premixed combustion dominates at a low load, and the fundamental combustion effects are more influential [38]. In Figure 6c, the overall analysis shows that the NOx emissions from the CRDI diesel engine fueled with B100 are only $13.08 \%$ greater than those of $\mathrm{B} 0$. This is because the presence of oxygen in biodiesel promotes combustion and raises the temperature in the combustion chamber, resulting in slightly higher NOx emissions from biodiesel than from diesel [39]. Moreover, the increase in NOx is related to the presence of unsaturated hydrocarbons in the fuel [40]. As shown in Figure 6d, the smoke opacity is the lowest at $0 \%$ engine load due to a high air/fuel ratio compared with other operating conditions. At $100 \%$ load, there is a clear increase in smoke opacity due to a large amount of fuel consumption and a decrease in 
oxygen concentration in the combustion chamber. Therefore, it can be concluded that a higher load results in lower fuel oxygen content [41]. In addition, smoke opacity decreases with the increase in the biodiesel blend ratio in the diesel fuel, and this behavior is more obvious at high engine loads. At $100 \%$ load, the smoke opacity of B10, B20, B30, and B100 are reduced by $30.26 \%, 47.23 \%, 64.95 \%$, and $90.78 \%$, respectively, compared with B0. These results are also easily verified in Figure 7, which shows the color depth of the filter papers covered with PM primary particles according to different collection times $(1,2$, and $5 \mathrm{~min})$. This is mainly because the oxygen contained in biodiesel improves diffusion combustion and promotes the post-flame oxidation of smoke during later expansion and exhaust processes. Additionally, soot formation is also associated with temperature and the soot volume fraction (SVF) [42,43]; the oxygen contained in biodiesel can also improve local anoxic conditions caused by fuel-rich zones. The biodiesel has a higher cetane number than diesel, which also can increase fuel combustion efficiency and reduce smoke opacity [41].
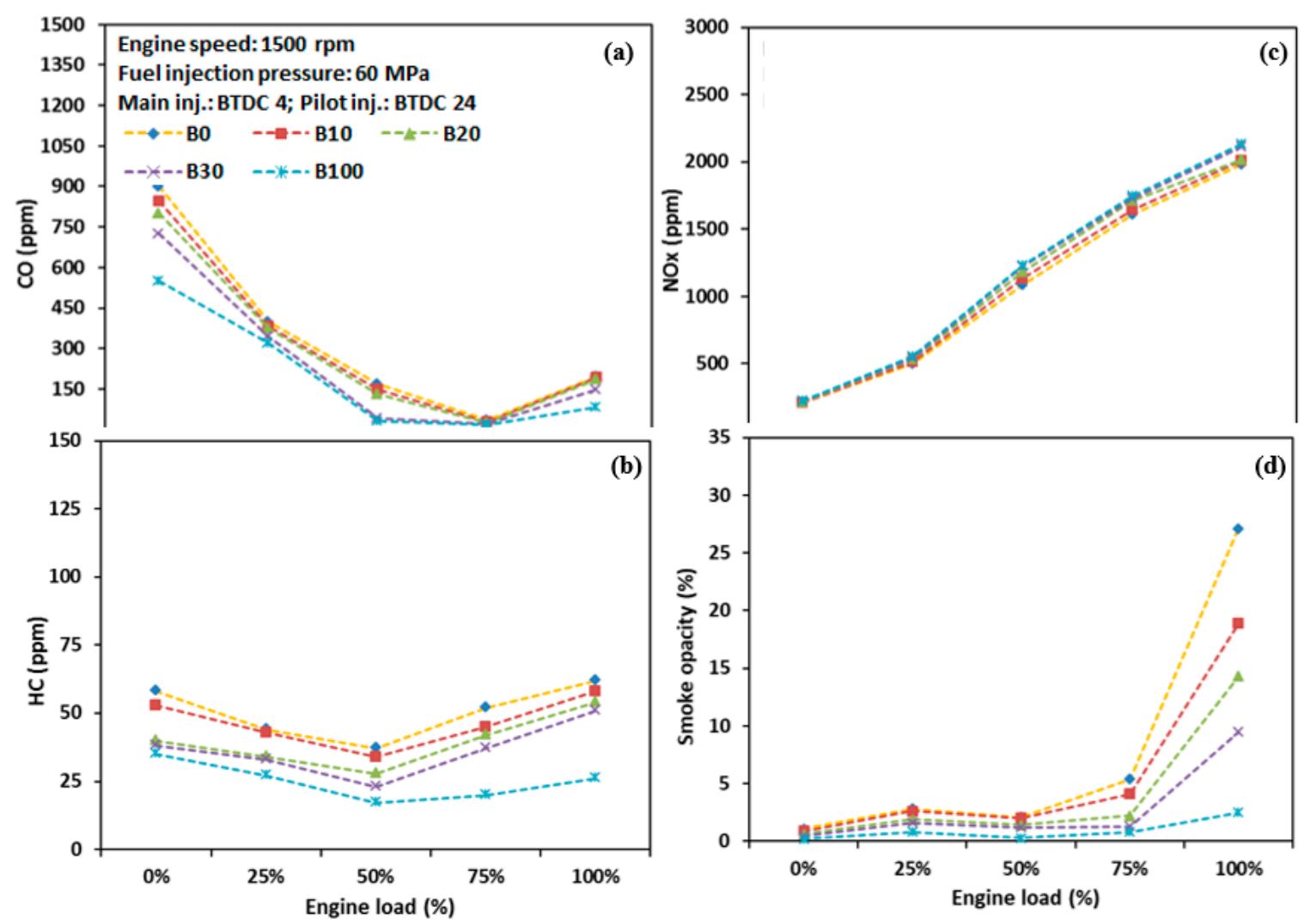

Figure 6. Effect of engine loads on (a) CO, (b) hydrocarbon (HC), and (c) nitrogen oxide (NOx) emissions and (d) smoke opacity.

Figures 8 and 9 show the TEM and SEM images of the PM primary particles emitted from the CRDI diesel engine fueled with biodiesel blends at $25 \%$ and $75 \%$ engine loads. As shown in Figures 8 and 9 , the diameters of the PM primary particles emitted from the CRDI diesel engine fueled with all tested fuels are much smaller than $100 \mathrm{~nm}$. Some of the PM primary particles are clustered together to form micron-sized agglomerates. Figure 10 shows the PM particle diameter distribution for all biodiesel blends. At 25\% load, the average diameter of the PM primary particles for B0, B10, B20, B30, and B100 is $32.35,25.66,24.71,23.91$, and $22.79 \mathrm{~nm}$, respectively; the minimum diameter of the PM primary particles for all tested fuels is about $10 \mathrm{~nm}$. At $75 \%$ load, the average diameter of the PM primary particles for all tested fuels are slightly further reduced; for B0, B10, B20, B30, and B100 the average diameter is $30.70,24.02,23.01,21.96$, and $20.71 \mathrm{~nm}$, respectively. Moreover, for B0, the diameter of the PM primary particles is mainly distributed between 15 and $50 \mathrm{~nm}$ with most particles having diameters between 30 and $40 \mathrm{~nm}$. For biodiesel blends, most of the PM primary particles have diameters mainly 
distributed between 20 and $30 \mathrm{~nm}$ (see Figure 10b). As a result, with the increases in the biodiesel mixing ratio and engine load, the average diameter of the PM primary particles decreases. This may be caused by increases in the combustion temperature and pressure in the combustion chamber and the combustion efficiency due to increased biodiesel mixing ratio and engine load, thereby increasing the oxidation rate of the PM primary particles. The oxygen content in the blended fuel increases with the addition of biodiesel to the diesel fuel, which improves the problem of insufficient oxygen in the oil-rich zone and promotes full combustion of the fuel. A similar phenomenon was also observed by Chong et al. [42]. On the other hand, the PM primary particles emitted from diesel engines mainly contain solid carbon cores $(0.01 \sim 0.08 \mathrm{~mm})$, agglomerate $(0.05 \sim 1.0 \mathrm{~mm})$ and adsorbed vapor-phase species, adsorbed hydrocarbons, liquid condensed hydrocarbon particles, and hydrated sulfate species [44]. In general, HCs and other substances adsorbed on the surface of PM are more easily oxidized under high-temperature and high-pressure conditions. Therefore, the decrease of the PM particle diameter is also related to the decrease in the substance adsorbed on the surface of the PM primary particles. This is consistent with the results reported by Li et al. [45]. They also pointed out that the change in the PM particle diameter is also related to the fuel's cetane number; a high cetane number of biodiesel resulted in a short premixed combustion period, a long diffusion combustion period, and increased PM oxidation time.
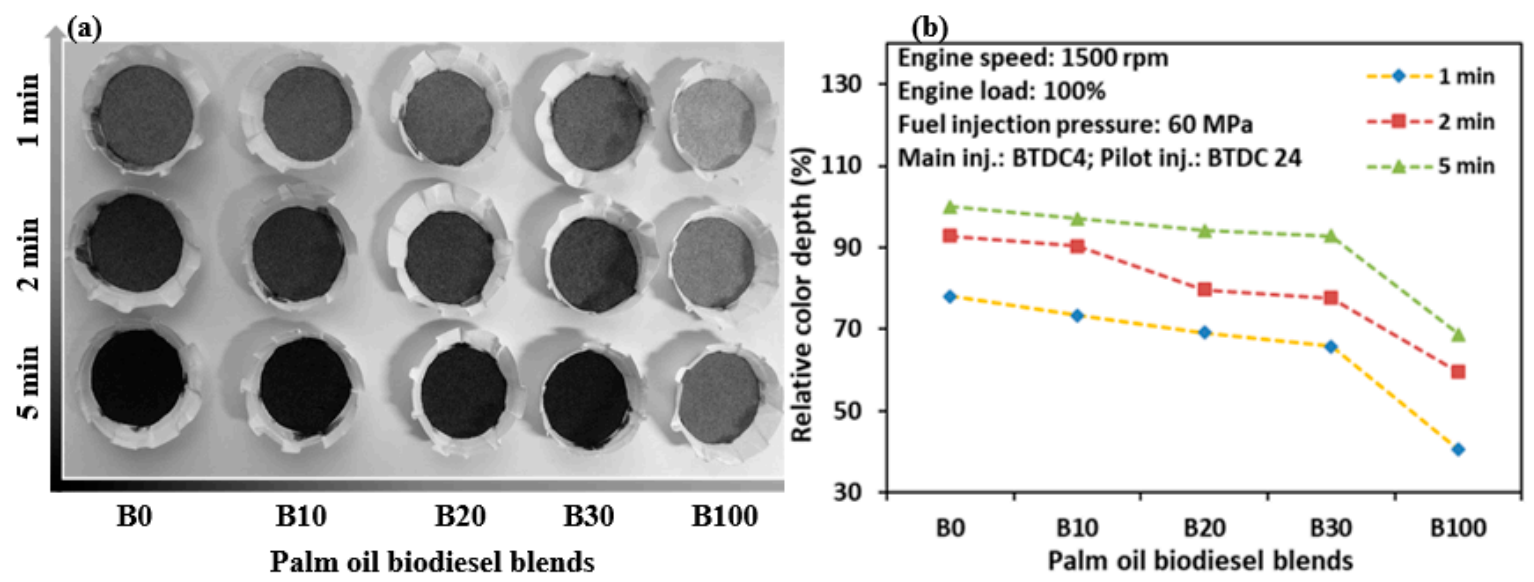

Figure 7. Photograph of filter papers covered with particles (a), and the color depth of the filter papers (b).

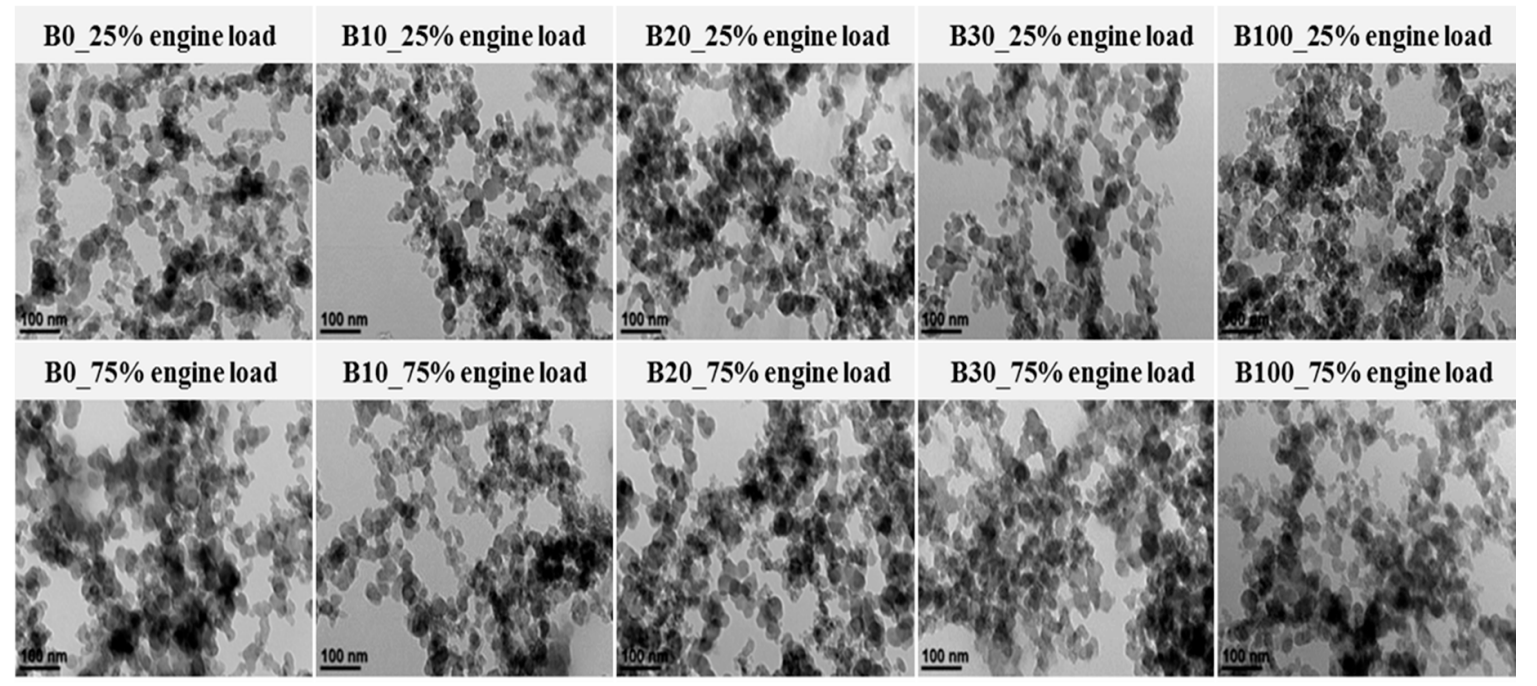

Figure 8. Comparisons of TEM images of the particulate matter (PM) primary particles at 25\% and $75 \%$ engine loads. 


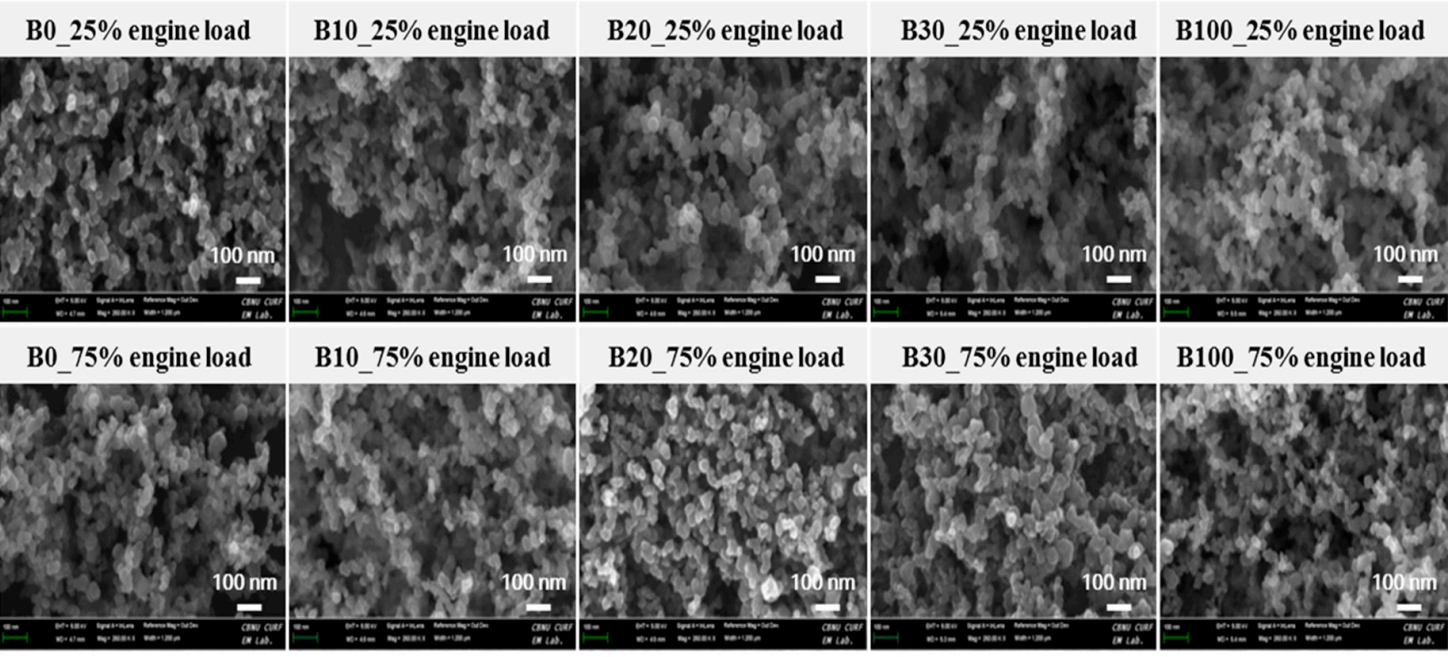

Figure 9. Comparisons of SEM images of the PM primary particles at $25 \%$ and $75 \%$ engine loads.

(a)

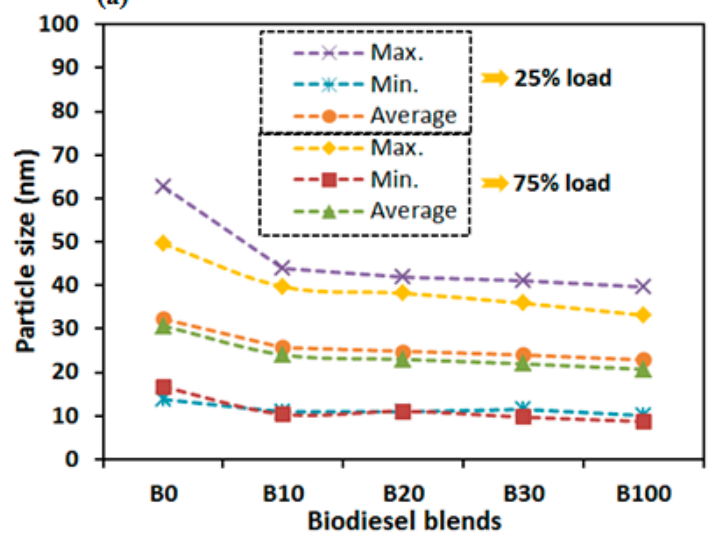

(b)

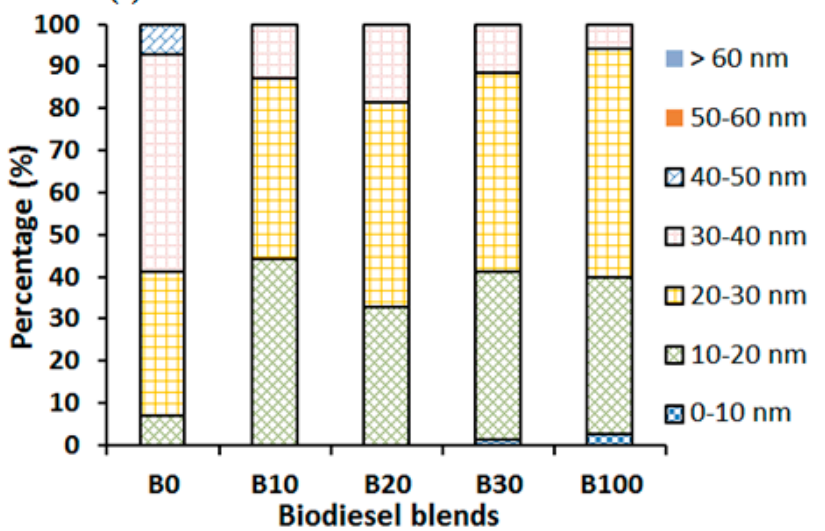

Figure 10. PM primary particle size (a) and its distribution at 75\% engine load (b).

Figure 11 presents the SEM images of filter papers without PM primary particles and filter papers covered with PM primary particles from all tested fuels at 100\% load according to different collection times (1 min and $2 \mathrm{~min}$ ). As shown in Figure 11, the filter paper without PM primary particles is made up of clear crisscrossing fibers with clearly visible voids between the fibers. As the PM primary particles collected on the filter paper, the visible amount of fibers on the filter paper decreased, and the voids between the fibers were filled with PM primary particles. With increasing capture time, the amount of visible fibers on the filter paper and pores between the fibers decreased significantly, which indicates an increase in the amount of PM primary particles on the filter paper. On the other hand, with increasing biodiesel blend ratios in diesel, especially for B100, the amount of PM primary particles on the filter paper is significantly reduced. Fewer PM primary particles were observed by the SEM on B100 samples compared with other samples. SEM allows the morphology of PM primary particles on filter paper to be observed in a relatively simple and clear way. These observations demonstrate that palm-oil-based biodiesel can play an important role as a reliable alternative fuel in reducing particulate emissions from diesel engines. 


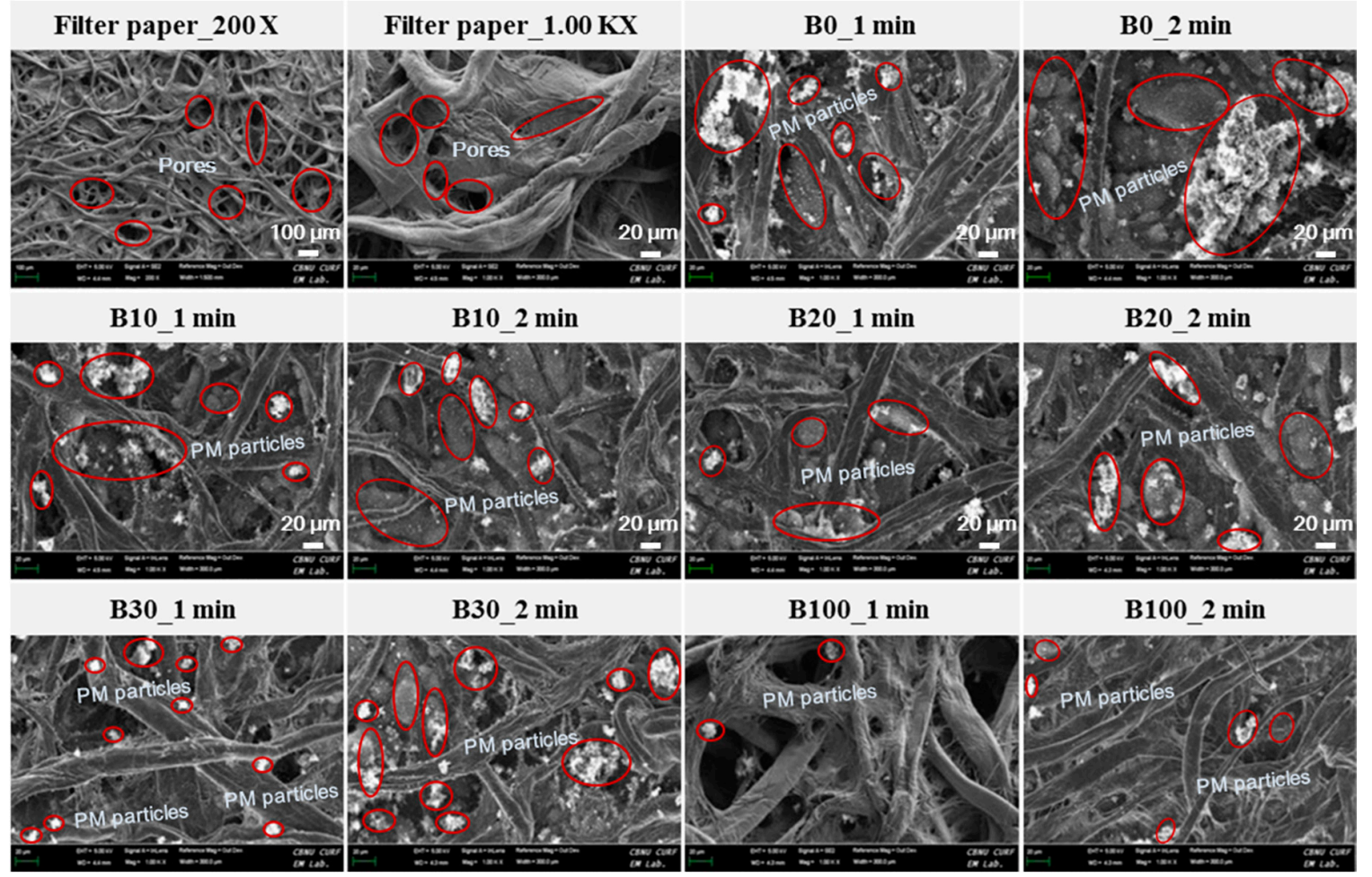

Figure 11. Comparisons of SEM images of paper filters covered with different amounts of particles.

\subsection{Unregulated Emission Characteristics}

Figure 12a compares the concentrations of three trace metals (TMs) (Mn, $\mathrm{Ba}$, and $\mathrm{Pb}$ ) emitted at $100 \%$ engine load from all the biodiesel blends. The TMs in the exhaust emissions show different trends with the change of the palm biodiesel blending ratio in diesel fuel. A high proportion of biodiesel does not keep the TMs at a very low level, and Shukla et al. [26] also found similar results. This may be attributed to some comprehensive effect affecting TM changes, such as fuel properties, engine operating conditions, and atomization effects during fuel injection. Patel et al. [46] and Shukla et al. [26] pointed out that there are three main sources of TMs in an engine exhaust system: (i) those present in fuels from production, processing, and transportation; (ii) those present in wear debris from friction between different engine components, such as pistons, piston rings, cylinder liner, and valve seats; and (iii) those present in lubricating oil from metal additives. Patel et al. [46] also pointed out that the variations in engine loads at constant speed are also very important for TM changes, because the lubricating oil composition and wear debris will be affected. Therefore, the engine operating conditions play an important role in the concentration of TMs emitted from the CRDI diesel engine. Overall, the TM changes are affected by a variety of complex factors such as fuel composition, lubricating oil composition, and engine operating conditions. In addition, TM emissions from diesel engines are very low, thus they are difficult to capture and analyze by general analysis techniques. Therefore, detailed analysis of the specific formation mechanism of TM emissions from diesel engines needs to be further studied in the future.

Figure $12 \mathrm{~b}$ shows the concentrations of benzene, toluene, and xylene (BTX) emissions from the CRDI diesel engine fueled with palm oil biodiesel-diesel blends at $25 \%$ and $75 \%$ loads. BTX are volatile organic compounds (VOCs). VOCs are numerous and complex, and the most common ones that pose the greatest threat to human health and the environment are BTX. Therefore, BTX are regarded as the main research object in this study. It was observed that the trends of BTX emissions are significantly affected by the load and biodiesel blend ratio. BTX emissions decrease with increasing engine load and biodiesel concentration in diesel. The overall analysis indicates that benzene emissions from all 
fuels are the greatest, followed by xylene (total o-xylene and p-xylene) and toluene. Similar results have been reported by other researchers [47-49]. Moreover, Liu et al. [50] found that the reduction of toluene was related to the addition of oxygenated fuels. These changes in BTX emissions may be mainly due to the combined effects of the following factors: (i) high engine load, with many studies showing that the high-temperature and high-pressure environment formed by a high load can promote BTX degradation; (ii) unsaturated hydrocarbon chains from biodiesel, because unsaturated hydrocarbons are the precursors responsible for the formation of aromatic and polycyclic aromatic hydrocarbons; (iii) pyrolysis products from diesel fuel, such as $\mathrm{C}_{2} \mathrm{H}_{4}$ and $\mathrm{C}_{3} \mathrm{H}_{6}$, whose presence increases the concentration of benzene; (iv) physicochemical properties of BTX, which decide whether BTX are easily degraded; (v) a high cetane number and high oxygen content in biodiesel, which improve combustion characteristics and promote BTX degradation; (vi) exhaust gas temperatures, because low exhaust temperature is not conducive to BTX degradation, especially for benzene; and (vii) other factors that are not conducive to BTX degradation, such as inappropriate engine operating parameters (e.g., low injection pressure), and shortcomings of biodiesel (e.g., high viscosity and high density). Thus, it may be concluded that the "positive effects" of high engine load and oxygen content in biodiesel and its high cetane number outweigh the "negative effects" of high viscosity and high unsaturated hydrogen from the biodiesel documented in this study, resulting in the reduction of BTX associated with increased biodiesel blend ratios and engine load.
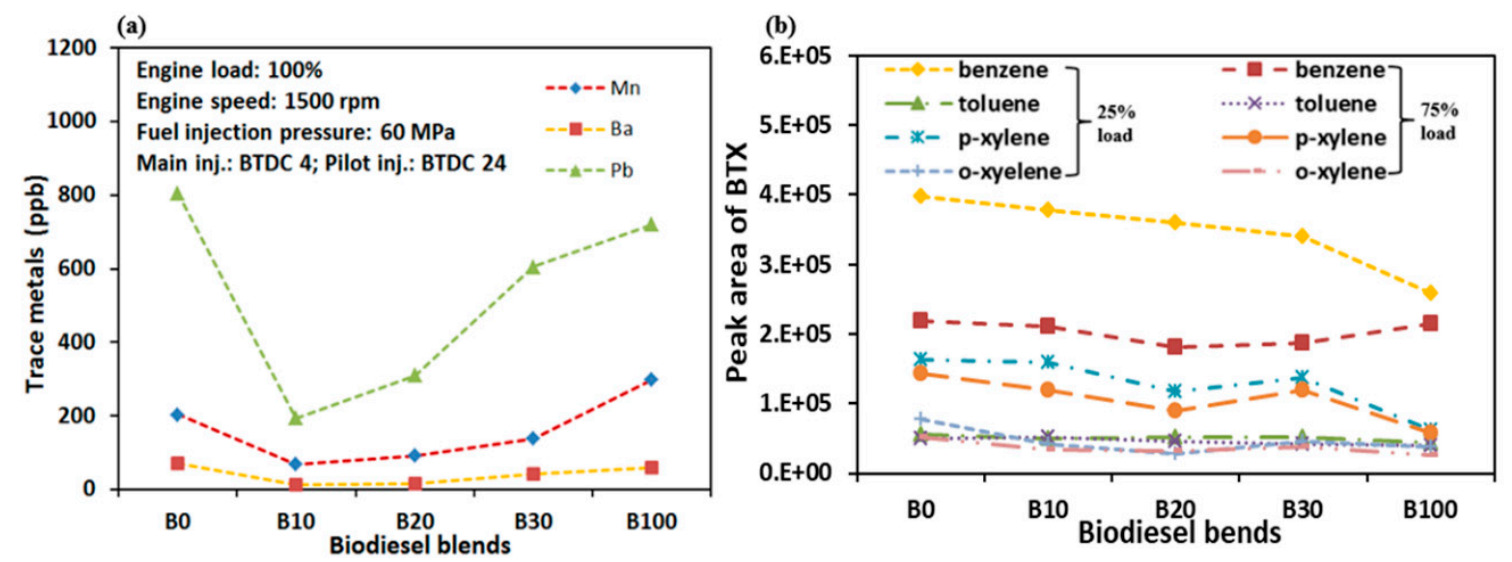

Figure 12. Trace metals (a) and peak area of benzene, toluene, and xylene (BTX) emissions (b) for all tested fuels.

\section{Conclusions}

To expand research on combustion, soot particle distribution, and regulated and unregulated emissions from diesel engines fueled with palm oil biodiesel, a series of experiments were carried out on a CRDI diesel engine with a constant speed of $1500 \mathrm{rpm}$ under wide engine loads from $0 \%$ to $100 \%$. The main conclusions are summarized as follows:

1. The influence of biodiesel blends on in-cylinder pressure and HRR has little change compared with pure diesel. The low calorific value and high viscosity of palm oil biodiesel results in higher brake specific fuel consumption (BSFC) than diesel, with an average of about $11.96 \%$ higher for all biodiesel blends under all engine operating loads. The COVimep for all biodiesel blends is much lower than $10 \%$, which shows that the CRDI diesel engine without any modification can run very stably under all operating conditions.

2. Compared to $\mathrm{B} 0$ fuel, the $\mathrm{CO}, \mathrm{HC}$, and smoke opacity are significantly reduced, while the NOx emissions are increased slightly under all engine loads in the CRDI diesel engine fueled with B10, B20, B30, and B100, respectively. Moreover, the PM primary particles for all test fuels are much smaller than $100 \mathrm{~nm}$ in diameter. The diameter of these particles further decreases with the increases in engine load and the biodiesel mixture ratio. At $75 \%$ load, the average diameters of 
the PM primary particles for B0, B10, B20, B30, and B100 are 30.70, 24.02, 23.01, 21.96, and 20.71 $\mathrm{nm}$, respectively, which are $5.10 \%, 6.39 \%, 6.88 \%, 8.16 \%$, and $9.13 \%$ lower than those at $25 \%$ load.

3. Unregulated emissions such as trace metals (TMs) including $\mathrm{Pb}, \mathrm{Mn}$, and $\mathrm{Ba}$ are found in the engine emissions, and the $\mathrm{Pb}$ content is the highest, followed by $\mathrm{Mn}$ and $\mathrm{Ba}$. The TM changes are affected by a variety of complex factors such as fuel composition, lubricating oil composition, and engine operating conditions. Of the BTX hydrocarbons, benzene is the highest in the emissions from all fuels, followed by xylene and benzene. BTX emissions are decreased by increased engine load and biodiesel content in diesel fuel.

Author Contributions: Methodology, J.C.G.; validation, J.C.G. and N.J.C.; investigation, J.C.G.; data curation, J.C.G.; writing-original draft preparation, J.C.G.; writing-review and editing, J.C.G. and N.J.C.; funding acquisition, J.C.G. and N.J.C. All authors have read and agreed to the published version of the manuscript.

Funding: This research was supported by the Basic Science Research Program through the National Research Foundation of Korea (NRF) funded by the Ministry of Education (No. 2019R1I1A1A01057727) and supported by the Korea government (MSIT) (No. 2019R1F1A1063154).

Acknowledgments: The authors would like to thank the teachers from the Center for University-Wide Research Facilities (CURF) at Jeonbuk National University (JBNU) for their help in performing the morphology of the PM particles.

Conflicts of Interest: All authors declare no conflict of interest.

\section{References}

1. Huang, H.; Huang, R.; Guo, X.; Pan, M.; Teng, W.; Chen, Y.; Li, Z. Effects of pine oil additive and pilot injection strategies on energy distribution, combustion and emissions in a diesel engine at low-load condition. Appl. Energy 2019, 250, 185-197. [CrossRef]

2. Chen, H.; Wang, M.; Wang, X.; Li, D.; Pan, Z.; Bae, C. Experimental investigation of particulate matter structures under partially premixed combustion in a compression ignition engine. Fuel 2020, 259, 116286. [CrossRef]

3. Chen, H.; Huang, R.; Huang, H.; Pan, M.; Teng, W. Potential improvement in particulate matter's emissions reduction from diesel engine by addition of PODE and injection parameters. Appl. Therm. Eng. 2019, 150, 591-604. [CrossRef]

4. Moon, G.; Lee, Y.; Choi, K.; Jeong, D. Emission characteristics of diesel, gas to liquid, and biodiesel-blended fuels in a diesel engine for passenger cars. Fuel 2010, 89, 3840-3846. [CrossRef]

5. Rao, Z.; Chen, Z.; Liang, H.; Huang, L.; Huang, D. Carbonyl compounds over urban Beijing: Concentrations on haze and non-haze days and effects on radical chemistry. Atmospheric Environ. 2016, 124, 207-216. [CrossRef]

6. Pesant, L.; Forti, L.; Jeuland, N. Effect of Fuel Characteristics on the Performances and Emissions of an Early-injection LTC / Diesel Engine. SAE Technical Paper Series 2008. [CrossRef]

7. Reşitoğlu, İ.A.; Altinişik, K.; Keskin, A. The pollutant emissions from diesel-engine vehicles and exhaust aftertreatment systems. Clean Technol. Environ. Policy 2014, 17, 15-27. [CrossRef]

8. Kwon, E.E.; Seo, J.; Yi, H. Transforming animal fats into biodiesel using charcoal and CO2. Green Chem. 2012, 14, 1799. [CrossRef]

9. Demirbaş, A. Biodiesel from vegetable oils via transesterification in supercritical methanol. Energy Convers. Manag. 2002, 43, 2349-2356. [CrossRef]

10. Levine, R.B.; Pinnarat, T.; Savage, P.E. Biodiesel Production from Wet Algal Biomass through in Situ Lipid Hydrolysis and Supercritical Transesterification. Energy Fuels 2010, 24, 5235-5243. [CrossRef]

11. Demirbas, A. Biodiesel from waste cooking oil via base-catalytic and supercritical methanol transesterification. Energy Convers. Manag. 2009, 50, 923-927. [CrossRef]

12. Wang, W.G.; Lyons, D.W.; Clark, A.N.N.; Gautam, M.; Norton, P.M. Emissions from Nine Heavy Trucks Fueled by Diesel and Biodiesel Blend without Engine Modification. Environ. Sci. Technol. 2000, 34, 933-939. [CrossRef]

13. Qi, D.; Chen, H.; Matthews, R.; Bian, Y. Combustion and emission characteristics of ethanol-biodiesel-water micro-emulsions used in a direct injection compression ignition engine. Fuel 2010, 89, 958-964. [CrossRef] 
14. Enweremadu, C.; Rutto, H. Combustion, emission and engine performance characteristics of used cooking oil biodiesel-A review. Renew. Sustain. Energy Rev. 2010, 14, 2863-2873. [CrossRef]

15. Chauhan, B.S.; Kumar, N.; Cho, H.M. A study on the performance and emission of a diesel engine fueled with Jatropha biodiesel oil and its blends. Energy 2012, 37, 616-622. [CrossRef]

16. Agarwal, A.K.; Rajamanoharan, K. Experimental investigations of performance and emissions of Karanja oil and its blends in a single cylinder agricultural diesel engine. Appl. Energy 2009, 86, 106-112. [CrossRef]

17. Roy, M.M.; Wang, W.; Bujold, J. Biodiesel production and comparison of emissions of a DI diesel engine fueled by biodiesel-diesel and canola oil-diesel blends at high idling operations. Appl. Energy 2013, 106, 198-208. [CrossRef]

18. Canakci, M.; Van Gerpen, J.H. Comparison of engine performance and emissions for petroleum diesel fuel, yellow grease biodiesel, and soybean oil biodiesel. Trans. ASAE 2003, 46, 937. [CrossRef]

19. Ng, H.K.; Gan, S. Combustion performance and exhaust emissions from the non-pressurised combustion of palm oil biodiesel blends. Appl. Therm. Eng. 2010, 30, 2476-2484. [CrossRef]

20. Habibullah, M.; Masjuki, H.; Kalam, M.; Fattah, I.R.; Ashraful, A.; Mobarak, H. Biodiesel production and performance evaluation of coconut, palm and their combined blend with diesel in a single-cylinder diesel engine. Energy Convers. Manag. 2014, 87, 250-257. [CrossRef]

21. An, H.; Yang, W.; Chou, S.; Chua, K. Combustion and emissions characteristics of diesel engine fueled by biodiesel at partial load conditions. Appl. Energy 2012, 99, 363-371. [CrossRef]

22. Salamanca, M.; Mondragón, F.; Agudelo, J.R.; Santamaría, A. Influence of palm oil biodiesel on the chemical and morphological characteristics of particulate matter emitted by a diesel engine. Atmospheric Environ. 2012, 62, 220-227. [CrossRef]

23. Bourrous, S.; Ribeyre, Q.; Lintis, L.; Yon, J.; Bau, S.; Thomas, D.; Vallières, C.; Ouf, F.-X. A semi-automatic analysis tool for the determination of primary particle size, overlap coefficient and specific surface area of nanoparticles aggregates. J. Aerosol Sci. 2018, 126, 122-132. [CrossRef]

24. Anderson, P.M.; Guo, H.; Sunderland, P.B. Repeatability and reproducibility of TEM soot primary particle size measurements and comparison of automated methods. J. Aerosol Sci. 2017, 114, 317-326. [CrossRef]

25. Ferreira, S.L.; Dos Santos, A.; De Souza, G.R.; Polito, W. Analysis of the emissions of volatile organic compounds from the compression ignition engine fueled by diesel-biodiesel blend and diesel oil using gas chromatography. Energy 2008, 33, 1801-1806. [CrossRef]

26. Shukla, P.C.; Gupta, T.; Labhsetwar, N.K.; Agarwal, A.K. Trace metals and ions in particulates emitted by biodiesel fuelled engine. Fuel 2017, 188, 603-609. [CrossRef]

27. Ge, J.C.; Kim, H.Y.; Yoon, S.K.; Choi, N.J. Reducing volatile organic compound emissions from diesel engines using canola oil biodiesel fuel and blends. Fuel 2018, 218, 266-274. [CrossRef]

28. Som, S.; Ramirez, A.I.; Longman, D.E.; Aggarwal, S.K. Effect of nozzle orifice geometry on spray, combustion, and emission characteristics under diesel engine conditions. Fuel 2011, 90, 1267-1276. [CrossRef]

29. Sahoo, P.; Das, L. Combustion analysis of Jatropha, Karanja and Polanga based biodiesel as fuel in a diesel engine. Fuel 2009, 88, 994-999. [CrossRef]

30. Wu, Y.; Huang, R.; Lee, C.F.; Huang, C. Effects of the exhaust gas recirculation rate and ambient gas temperature on the spray and combustion characteristics of soybean biodiesel and diesel. Proc. Inst. Mech. Eng. Part D J. Automob. Eng. 2011, 226, 372-384. [CrossRef]

31. Dhar, A.; Agarwal, A.K. Performance, emissions and combustion characteristics of Karanja biodiesel in a transportation engine. Fuel 2014, 119, 70-80. [CrossRef]

32. Raheman, H.; Ghadge, S. Performance of compression ignition engine with mahua (Madhuca indica) biodiesel. Fuel 2007, 86, 2568-2573. [CrossRef]

33. Suresh, M.; Jawahar, C.; Richard, A. A review on biodiesel production, combustion, performance, and emission characteristics of non-edible oils in variable compression ratio diesel engine using biodiesel and its blends. Renew. Sustain. Energy Rev. 2018, 92, 38-49. [CrossRef]

34. Uyumaz, A.; Solmaz, H.; Yilmaz, E.; Yamık, H.; Polat, S. Experimental examination of the effects of military aviation fuel JP-8 and biodiesel fuel blends on the engine performance, exhaust emissions and combustion in a direct injection engine. Fuel Process. Technol. 2014, 128, 158-165. [CrossRef]

35. Shirneshan, A.; Almassi, M.; Ghobadian, B.; Borghei, A.; Najafi, G. Effects of Biodiesel and Engine Load on Some Emission Characteristics of a Direct Injection Diesel Engine. Curr. World Environ. 2012, 7, $207-212$. [CrossRef] 
36. Monyem, A.; Van Gerpen, J.H. The effect of biodiesel oxidation on engine performance and emissions. Biomass- Bioenergy 2001, 20, 317-325. [CrossRef]

37. Kwanchareon, P.; Luengnaruemitchai, A.; Jai-In, S. Solubility of a diesel-biodiesel-ethanol blend, its fuel properties, and its emission characteristics from diesel engine. Fuel 2007, 86, 1053-1061. [CrossRef]

38. Hoekman, S.K.; Robbins, C. Review of the effects of biodiesel on NOx emissions. Fuel Process. Technol. 2012, 96, 237-249. [CrossRef]

39. Wang, X.; Cheung, C.; Di, Y.; Huang, Z. Diesel engine gaseous and particle emissions fueled with diesel-oxygenate blends. Fuel 2012, 94, 317-323. [CrossRef]

40. Mangesh, V.; Padmanabhan, S.; Tamizhdurai, P.; Ramesh, A. Experimental investigation to identify the type of waste plastic pyrolysis oil suitable for conversion to diesel engine fuel. J. Clean. Prod. 2020, 246, 119066. [CrossRef]

41. Ghadikolaei, M.A.; Wei, L.; Cheung, C.S.; Yung, K.-F. Effects of engine load and biodiesel content on performance and regulated and unregulated emissions of a diesel engine using contour-plot map. Sci. Total. Environ. 2019, 658, 1117-1130. [CrossRef] [PubMed]

42. Chong, C.T.; Tian, B.; Ng, J.-H.; Fan, L.; Ni, S.; Wong, K.Y.; Hochgreb, S. Quantification of carbon particulates produced under open liquid pool and prevaporised flame conditions: Waste cooking oil biodiesel and diesel blends. Fuel 2020, 270, 117469. [CrossRef]

43. Ma, L.; Ning, H.; Wu, J.; Cheong, K.-P.; Ren, W. Characterization of Temperature and Soot Volume Fraction in Laminar Premixed Flames: Laser Absorption/Extinction Measurement and Two-Dimensional Computational Fluid Dynamics Modeling. Energy Fuels 2018, 32, 12962-12970. [CrossRef]

44. Twigg, M.V.; Phillips, P.R. Cleaning the Air We Breathe - Controlling Diesel Particulate Emissions from Passenger Cars. Platin. Met. Rev. 2009, 53, 27-34. [CrossRef]

45. Li, R.; Wang, Z. Study on status characteristics and oxidation reactivity of biodiesel particulate matter. Fuel 2018, 218, 218-226. [CrossRef]

46. Patel, C.; Chandra, K.; Hwang, J.; Agarwal, R.A.; Gupta, N.; Bae, C.; Gupta, T.; Agarwal, A.K. Comparative compression ignition engine performance, combustion, and emission characteristics, and trace metals in particulates from Waste cooking oil, Jatropha and Karanja oil derived biodiesels. Fuel 2019, 236, 1366-1376. [CrossRef]

47. Cheung, C.; Zhu, L.; Huang, Z. Regulated and unregulated emissions from a diesel engine fueled with biodiesel and biodiesel blended with methanol. Atmospheric Environ. 2009, 43, 4865-4872. [CrossRef]

48. Zhou, J.; Cheung, C.; Zhao, W.; Leung, C. Diesel-hydrogen dual-fuel combustion and its impact on unregulated gaseous emissions and particulate emissions under different engine loads and engine speeds. Energy 2016, 94, 110-123. [CrossRef]

49. Di, Y.; Cheung, C.; Huang, Z. Experimental investigation on regulated and unregulated emissions of a diesel engine fueled with ultra-low sulfur diesel fuel blended with biodiesel from waste cooking oil. Sci. Total. Environ. 2009, 407, 835-846. [CrossRef]

50. Liu, H.; Zhang, P.; Liu, X.; Chen, B.; Geng, C.; Li, B.; Wang, H.; Li, Z.; Yao, M. Laser diagnostics and chemical kinetic analysis of PAHs and soot in co-flow partially premixed flames using diesel surrogate and oxygenated additives of n-butanol and DMF. Combust. Flame 2018, 188, 129-141. [CrossRef]

Publisher's Note: MDPI stays neutral with regard to jurisdictional claims in published maps and institutional affiliations.

(C) 2020 by the authors. Licensee MDPI, Basel, Switzerland. This article is an open access article distributed under the terms and conditions of the Creative Commons Attribution (CC BY) license (http://creativecommons.org/licenses/by/4.0/). 